\title{
PREFACE
}

\section{THE INTERNET AS A NEW CHANCE FOR ACADEMIC COMMUNITIES}

\section{ALEKSANDER KOBYLAREK}

Some universities in Central and Eastern Europe are facing a crisis of identity. Academic institutions have for centuries developed independence, liberal education and independent research. Freedom and independence have always been essential for the quality of academic work. Thanks to this, scholars and scientists were restricted only by their own ignorance, which in its turn, was restricted by experience. It meant that the age of the scholar was usually connected to his knowledge. The older scientist had to be smarter and wiser.

The experienced and wise scholars established scientific schools and communities, which supported and disseminated the ideas of the master and founder especially after his death. For that reason - scientific schools and communities were always one of the most important manifestations of the scientific activity of the people. Some scholars never like working in the community and are motivated only towards scientific goals and in many cases much of the work done was just a pure waste of time due to lack of the support of other potential contributors.

Over time a specific hierarchy formed. Finally, science became the result of collective action directed by prescribed priests of knowledge called professors. The status of the university professor in some European countries in the 20th century was equal to that of president of the state. It was the supreme example of power created and supported by knowledge. In times of mass media the magic of the academic title became so strong that professors started to become sort of scientific celebrities, very often consulted on problems unrelated to their discipline and not even related to the problems of science, frequently totally irrelevant or bizarre.

The great success of American science presaged a change in thinking about the European style of research and financing of scientists' activities. The Bologna Process is an example of a kind of change in thinking about the future of the European science and the place of Academia. Many efforts in European countries concentrated on searching for new ways of accelerating science.

The main problem lies in the fact that the concept of financing and development of science from the Lisbon Treaty was not accepted by the scientific communities in many countries. The ideas of professionalization and practical effects of research were alien to the Humboldtian idea of the university.

Nowadays we have 3 different orientations in academic teaching and 3 concepts of producing science :

- the Humboldtian idea- university and researchers are totally independent,

- chaos in scientific values- a state of affairs in which nobody knows the rules, 
- the post Bologna concept, which is characterized by pragmatism and acceleration.

The Humboldtian idea of the university still seems to work in Central and Eastern Europe in the so called post communist countries although the countries which have accepted the rules of the Bologna Process are at a more advanced stage: chaos in scientific values and in rules of organization of science. The situation seems to be very bad in the area of Geisteswissenschaften (humanities and social sciences), which have seen significant importance in the development of academic communities.

The problems of the Humboldtian concept of scientific work is the insistence on lack of communication with the members of the world extra muros, outside of Academia. This independence of scientists has led to:

- $\quad$ academic feudalism (every researcher 's career was practically DEPENDENT on somebody else, who seemed to be better or wiser or just had power at the university),

- $\quad$ elitism- very strict groups of people took control of scientific discipline and made decisions about the future of other academics,

- lack of the research process or trivial research with little importance for the economy and real life.

In Humboldtian science very important ideas were the rule ; on the meaning of Plato, models, theories, structures and beautiful, complicated language, - the more complicated the text the better. In many cases the texts of the best professors were comprehensible only to a few of the best professors in the discipline. Of course the situation is acceptable if we are thinking only about elitist science, which is a sacrum itself and cannot be understood (or used) by mere mortals

The elitist science seemed to be the dominating pattern of development up to the 20th century, when the higher developed countries achieved the level of the knowledge societies as well as the steadily increasing level of education and need for highly qualified specialists.

Traditionally developed science seemed to be the best option for the support of society but many years ago Peter Drucker in the book Post-Capitalist Society was the first author to write about useless liberal education.

The problem of the Humboldtian formula and liberal science lies not only in independence from practice and reality of work extra muros. The more serious problem of the traditional university in the new situation started to be the self same value which had been most important up till then. The first assumed truththe authority of the university professor is not sufficient any more. 30 years ago the Sokal hoax proved it.

The Bologna Process revealed many abnormalities in so called liberal education and traditional independent producing of science in the universities. Independence was not an abstract word. It was related to the world extra muros while intra muros we have had to face strong dependence on people, whose abilities to govern, manage and make administrative decisions were relatively weak.

The reason for this situation was academic feudalism. Before the Bologna Process nobody questioned the management abilities of the university professors, 
who often had to manage the smaller or bigger university units. Nowadays, when we compare the post-Humboldian feudal academic structure with the best univesities in the world, it must be accepted that one of the strong points of the best American universities is professional management of the faculty. The changes to the European universities should start with management and organization not from didactics.

The situation in Polish science and at the universities is very complicated and could serve as an example of the period of chaos in scientific values, a fact that could be very interesting for society, seeking to make science more significant . On the one hand we have progress in the Bologna Process but on the other hand there exists still some kind of resistance among the older feudal scientists. In 2011 the new act on higher education was established in which there are clearly defined new rules for the promotion of science but individual professors and boards are ignoring it. The track of promotions should be (according to the law) faster but the professors are making it harder and slower. The observed effect is that we forget about the utility, internationalization and making better science. The best Polish universities in many international classifications have not improved since the year 2011.

Changes in promoting and making science after the year 2011 and the resistance of the traditionalists led to strange consequences- for example the reviewers have almost the same or often less important academic achievements (according to the new criteria) than the proposed candidates for professors.

The case of Poland could be a warning for other countries of the region, which would like to change their pattern of making science. If we would like to change the system from feudal and Humboldtian into the world of competition, we should do it without any hesitation and quickly or... abandon all hope for many years.

The war of paradigms of making science is totally unfair to all younger scientists, who are dependent on the whims of senior researchers and managing professors. The rules can be obeyed but it might be not enough for promotion. In this case good will is the only factor which decides about promotion or failure.

In recent years Poland revealed many curiosities and even pathological decisions, which never would have been revealed in the Humboldtian university. The scale of the pathology is possible to reveal and define because of the transparency of the internet communities of the young scientists, who try to find any kind of support following unfair decisions by professors and non professional managers of science.

The pathologies in science most mentioned in the Polish internet communities are usually connected with the promotion of younger scientists:

- little help or lack of help in the process of promotion - professors are not interested in promoting the best students because of the fear of competition,

- unfair competition after PhD for the position of assistant professor (conditions are usually very strictly defined - only one candidate, who is preferred by the board, could fulfill the needed requirements),

- unclear or even unfair rules of evaluation of scientific achievements,

- low income or lack of income during the PhD studies (the lack of scholar- 
ship practically eliminates the students because if they have to work- they don't have time for research),

- low possibility or lack of possibilities of getting positions at universities. In Poland there are only scientific doctorates, which predetermine to the work for Academia, where the number of hired researchers and professors is restricted.

Internet communities are the real chance for changing the unfair rules of the scientific game from feudal to more democratic. At the moment we have some groups or blogs which concentrate on the unfair action at the university. The authors are relating cases and decisions (or lack of decisions) and friends or other younger researchers are observing and waiting for the results of the battle. Some cases face such tough feudal academic resistance, that the younger candidates will have to sue the procedures or decision- makers.

On another level the younger researchers are using the internet communities to share their first scientific experiences and to find other researchers involved in the same kinds of scientific projects or who are interested in similar topics. It seems to be the future of science. At the same time when the universities became closed and non-participative, we find the most important values of the first universities, openness and free thinking, in the internet communities. In the traditional Humboldtian university time and space were the main factors of development of the mind. The master and the student had to meet at the same time and in a common space. The master was usually the only teacher. In the internet communities the only time we need for learning is the time for development of the mind. We don't need the physical space. And masters can be found everywhere depending only on the needs of the student.

In this situation we should open science as much as possible. We should do it in the internet communities, through making discussion groups, platforms, online courses, fan pages, scientific blogs and publishing with open access. Within this new free market of ideas the great minds will quickly find very well motivated students. 